\title{
Dependence of standing crop on range condition rating in New Mexico
}

\author{
JAMES A. TIEDEMAN, RELDON BECK, AND ROBIN VANHORN ECRET
}

\begin{abstract}
The Sandy Ridge Site of southern New Mexico was studied to determine the dependance of total standing crop and components of standing crop on range condition rating. Total standing crop which included mesquite (Prosopis glandulosa Torr.) decreased, but total standing crop minus mesquite increased as range condition rating increased. These relationships were found to be highly significant $(P \leq 0.01)$ by regression analysis. Very low $R$-square values for these models indicate that the often assumed positive linear relationship of standing crop to range condition rating is not reliable. Prediction of standing crop from range condition ratings using linear or quadratic models was found to be unreliable for the Sandy Range Site in southern New Mexico.
\end{abstract}

Key Words: ecological status, trend, forage production, biomass

Range condition classification has become the basis for adjusting stocking rates and revising management plans, a procedure which has resulted in considerable controversy. One commonly used procedure, developed by Dyksterhuis (1949), assumes that forage production increases as range condition increases. This study was conducted to determine if this relationship applies to a rangeland area classified and mapped as the Sandy Range Site in southern New Mexico.

With the Dyksterhuis method, rangelands in early stages of secondary succession are classified poor while those in climax stages are excellent. The procedure is based on estimating the percentage of the present plant species composition by aerial cover or weight that is considered to be part of the climax stage of succession for the site.

Four condition classes are:

$\begin{array}{ll}\text { Poor } & 0 \text { to } 25 \% \text { of climax } \\ \text { Fair } & 25 \text { to } 50 \% \text { of climax } \\ \text { Good } & 50 \text { to } 75 \% \text { of climax } \\ \text { Excellent } & 75 \text { to } 100 \% \text { of climax }\end{array}$

The Range Inventory Standardization Committee (1983) proposes that the term range condition be replaced with ecological status and the classes of poor, fair, good, and excellent be replaced with the classes of early seral, mid seral, late seral, and potential natural community, respectively. The plant species composition in the potential natural community (often called climax) of a "Range Site" is determined by using areas subjected to minimal disturbance that have been excluded from grazing for long periods of time (relic areas).

Many range managers recommend or set lower stocking rates on poor condition range relative to good condition range based upon the assumption that forage production is lower in lower condition classes (Dyksterhuis 1949, USDA 1976). This assumption was supported by Goebel and Cook (1960) in southern Utah. They found that poor condition range had lower forage production with less palatable forage than good condition range. Infiltration rates

\footnotetext{
Authors are associate professor, Washington State University, Pullman 991646410; professor of range science, Department of Animal and Range Sciences, New Mexico State University, Las Cruces 88001 ; and research/extension program assistant, Washington State University, Pullman 99164-6410.

This study was approved by the Director, Washington State University College of Agriculture and Home Economics Research Center, as Scientific Paper 7531, Project 0698, and was supported by the Range Improvement Task Force of New Mexico State University. The authors wish to thank Drs. J.R. Alldredge, G.M. Southward, T.S. Russell, and R.C. Chapman for their assistance and advice in statistical analysis. Manuscript accepted 11 April 1991.
}

of water into the soil were also the lowest on the poor condition range. Other studies conflict with this assumption. Cook et al. (1965) found slightly more total forage produced on range in the poor condition class than range in the good condition class.

Smith (1979) found that the method used to rank range by condition classes is inadequate and proposed that it be modified. His assertion was that range condition based on climax composition may not be meaningful in terms of management and that climax or near-climax condition classes may not be as desirable to the land manager's goals as the lower condition classes. For example, on range where sagebrush (Artemisia tridentata Nutt.) has been destroyed, forage production is usually higher but condition rating is lower than excellent condition range where sagebrush remains as part of the climax plant community. Modifications to current condition concepts have been suggested by the Range Inventory Standardization Committee (1983). The state-andtransition model (Westoby et al. 1989) is an alternative to the range condition model. It emphasizes management for transition to desired stable states rather than adjustment of stocking rate toward succession along a gradient towards climax as practiced under the range condition model. The objectives of our study were to:

a) determine if there is a dependence of various components of standing crop on range condition rating (i.e., if forage production increases as range condition rating increases),

b) quantify the amount of change in standing crop for a given change in range condition rating, and

c) determine how accurately estimated standing crop can be predicted from range condition rating using a simple linear model (the model most commonly applied).

\section{Study Area}

Field sampling was conducted from 18 August to 22 October 1977, on the New Mexico State University's Agricultural Experiment Station Ranch, $20 \mathrm{~km}$ north of Las Cruces. The climate is arid with the mean annual precipitation for a 40-year period of 215 $\mathrm{mm}$, most of which falls during the growing season (July, August, and September). June is the warmest month of the year with an average maximum temperature of $34^{\circ} \mathrm{C}$. January is the coolest month of the year with an average of $13^{\circ} \mathrm{C}$. The precipitation in 1977 during this study period was slightly above normal in August and October, but only $15 \%$ of the normal for September (U.S. Department of Commerce 1977).

Data were collected from 2 similar areas, each containing areas varying from poor to good condition. Previously in 1967, one of the areas was fenced into 3 pastures to separate the predominantly good condition range designated pasture $3 \mathrm{~N}$, ( $451 \mathrm{ha})$; fair condition range, pasture $3 \mathrm{~W},(668 \mathrm{ha})$; and poor condition range, pasture $3 S,(526$ ha). The 3 pastures had been grazed under a seasonal suitability grazing system (Beck 1978). The other area, pasture 15 $(1,348 \mathrm{ha})$, was continuously grazed.

The study area is classified as semidesert grassland with the vegetation varying from homogeneous stands of black grama (Bouteloua eriopoda Torr.) to nearly pure stands of mesquite. Extensive sand dunes have developed where mesquite has invaded these sandy soils. The study area is described and mapped as 
“Sandy Range Site" (USDA 1979).

\section{Methods}

One hundred twenty transects were sampled in the study area using ten $0.89-\mathrm{m}^{2}$ quadrats per transect. Fifty six, 24, 20, and 20 transects were randomly located in pastures $15,3 \mathrm{~W}, 3 \mathrm{~S}$, and $3 \mathrm{~N}$ respectively. Standing crop green weight of each species in a quadrat was estimated in the field according to the methods developed by Pechanec and Pickford (1937) and tested by others as summarized by Cook and Stubbendieck (1986). Standing crop was the total amount of living plant material in aboveground parts, expressed on a per unit area basis at a given point in time. Field personnel were trained by estimating, then clipping and weighing practice plots prior to actual sampling. Estimated plots were occasionally clipped during sampling to verify and if necessary modify estimates. Plants of each species were harvested monthly, weighed green, then air dried each month to develop conversion factors to convert green weights to air-dry weights on a monthly basis. Woody material from previous years' growth was not included in the estimates.

Range condition ratings were determined for each sample transect according to the Dyksterhuis (1949) method as currently used and modified by the SCS (USDA 1976). With this method, the species composition of the potential plant community (Table 1) was compared to the species composition of the plant community of each sample transect. Range condition rating was determined by the summation of the percentage values of species or categories of species common to both plant communities. As described by USDA (1976), the range condition rating is an expression of the relative degree to which the plant species composition of the sample community resembles the presumed climax plant community for the Sandy Range Site. Of the 120 transects, 35, 49, and 36 were classified according to this method as poor, fair, and good condition, respectively.

Regression analysis of 120 sample values was used to determine the dependence of various components of estimated standing crop (y) on range condition rating $(x)$ for the type of rangeland in southern New Mexico classified and mapped Sandy Range Site.

We evaluated not only total standing crop but also various components of total standing crop because some plant species such as mesquite or broom snakeweed (Xanthocephalum sarothrae (Pursh) Shinners) are not useful as forage for livestock in this study area (Rosiere et al. 1975), which directly impacts carrying capacity. The relationship of range condition rating and carrying capacity, was evaluated by comparing range condition rating to (a) total standing crop, (b) total standing crop minus mesquite and (c) components of total standing crop. Components of the total standing crop were total grasses, perennial grasses, annual grasses, perennial forbs, annual forbs, black grama, and a number of individual plant species.

Simple linear models were used to test these relationships. Data transformations and quadratic models were used to further evaluate the dependence of standing crop on range condition rating.

\section{Results and Discussion}

Significant linear relationships $(p \leq 0.05)$ were determined by regression analysis between various components of standing crop (y) and range condition rating (x). A highly significant negative linear relationship was found between total standing crop and the range condition rating. Although significant, the $\mathrm{R}$-square value $(0.43)$ for the linear model is low, only explaining $43 \%$ of the total variation. The quadratic model $y=965.9-28.4 x+0.2 x^{2}$ had a much better fit, explaining $57 \%$ of the total variation (Fig. 1).

These data are interpreted as showing that as the composition of climax species increases (i.e., as range condition improves) the total nonwoody standing crop of the Sandy Range Site decreases. However, most of the total standing crop from the poor condition rangeland is from the unpalatable mesquite. The greatest percentage dry weight of the total standing crop is mesquite with an average of $58 \%$ for the 120 transects (Table 2).

Table 1. Composition of the potential plant community for the Sandy Range Site. Approximate percentage of total annual herbage yield expressed in air-dry weight (lb) per acre (USDA 1979).

\begin{tabular}{lllll}
\hline \hline Grasses \& grasslike & $70-75 \%$ & $\begin{array}{l}\text { Woody (Shrubs, half shrubs, vines } \\
\text { and trees) }\end{array}$ & $10-15 \%$ & Forbs \\
\hline Black grama & $20-30$ & $\begin{array}{l}\text { Soaptree yucca } \\
\text { Longleaf ephedra }\end{array}$ & $5-10$ & $\begin{array}{l}\text { Croton } \\
\text { Wild buckwheat } \\
\text { Globemallow } \\
\text { Euphorbia spp. }\end{array}$
\end{tabular}

Mesa dropseed

Sand dropseed

Spike dropseed

15-20

Bush muhly
Plains bristlegrass
Arizona cottontop
Cane bluestem

Tobosa

$1-5$

Threeawns

5-10

Fluffgrass

Annual grasses

Blue grama
Sand sagebrush
Fourwing saltbush
Winterfat
Broom dalea

5-10

1-5

Cacti

Broom snakeweed

\section{1-5}

Spectaclepod

Desert baileya

Filaree

1-3

1-3
Threadleaf groundsel Desert holly Astragalus spp.

Horsenettle Russian thistle Lambsquarters Tansymustard 


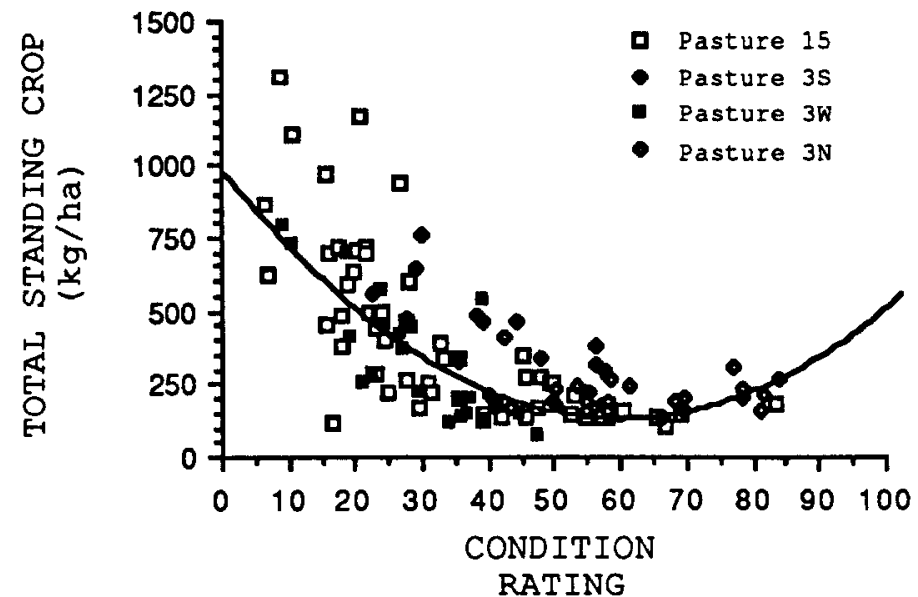

Fig. 1. Total standing crop (kg/ha) in relation to condition rating. Regression curve is best fit quadratic equation: $y=965.9-28.4 x+0.2 x^{2}, R^{2}=$ $0.57, P \leq 0.01$

A proper evaluation of range carrying capacity as related to range condition must be directed toward that portion of the vegetation considered useful as forage for livestock or wildlife. A positive rather than negative relationship is found between standing crop and range condition rating when the unpalatable mesquite is eliminated from the total standing crop. Although the regression of total standing crop minus mesquite $(y=94.9+0.9 x)$ has a significant positive relationship to condition rating, it explains very little, only $8 \%\left(R^{2}=0.08\right)$ of the variation. An extremely low $R^{2}$ value implies that $y$ has virtually no linear dependency on $x$ (Lewis-Beck 1986). This relationship is low, negative, or nonsignificant when tested within each pasture.

The relationship of grass standing crop to condition rating was positive $(y=15.4+1.1 \mathrm{x})$ and significantly correlated $\left(R^{2}=0.34\right)$ when tested across all pastures. The relationship was either low $\left(R^{2}<0.16\right)$ or nonsignificant when tested within each pasture except $3 \mathrm{~N},\left(y=-5.2+1.5 \mathrm{x}, \mathrm{R}^{2}=0.34\right)$, the pasture with the highest mean condition rating $(62.6)$.

The relationship of perennial grass standing crop to condition rating was positive $(y=17.8+1.0 x)$ and significantly correlated $\left(R^{2}\right.$ $=0.30)$ across all pastures but was low $\left(R^{2}<0.30\right)$ or nonsignificant when tested within each pasture. Mesa dropseed (Sporobolus flexuosus (Thurb.) Rydb.) and black grama had the greatest percent composition by weight of the grass species present $(10.4 \%$ and $3.5 \%$ respectively, Table 2). Separate regression analyses were done on these species. Mesa dropseed had a low but significant correlation $\left(R^{2}=0.03\right)$ to condition rating. This relationship was not significant across any of the regressions for the separate pastures.

The linear relationship of perennial grass to condition rating was mostly attributed to the black grama standing crop, the second most abundant grass. Black grama had a positive significant correlation $\left(R^{2}=0.32\right)$ to condition rating with the linear model $y=-13.3$ $+0.6 \mathrm{x}$ but an even better correlation $\left(R^{2}=0.48\right)$ with the quadratic model: $y=15.3-1.1 x+0.02 x^{2}$. The black grama linear relationship was significant for separate pastures $15\left(y=-7.6+0.6 x, R^{2}=0.28\right)$ and $3 \mathrm{~N}\left(\mathrm{y}=-64.0+1.6 \mathrm{x}, \mathrm{R}^{2}=0.43\right)$. This relationship was not analyzed for pastures $3 \mathrm{~W}$ and $3 \mathrm{~S}$, since black grama was present in only 5 transects within these pastures. The relationship of the annual grass portion of standing crop to range condition rating was also low but positive $(y=-2.3+0.1 \mathrm{x})$ and significant $\left(R^{2}=\right.$ 0.24). This relationship is not significant for the separate pastures except pasture $3 \mathrm{~N}\left(R^{2}=0.20\right)$. Neither total forbs, perennial forbs, nor annual forbs were significantly related to condition rating. The separate analysis of Russian thistle (Salsola kali L.), a species contributing the greatest percentage of the annual forb standing
Table 2. Average percent species composition by estimated dry weight for 120 transects, and percent species frequency of occurrence for the Sandy Range Site. Species lower than $\mathbf{0 . 1 \%}$ composition are not listed.

\begin{tabular}{|c|c|c|}
\hline Species & $\begin{array}{c}\% \\
\text { Composition } \\
\text { by dry } \\
\text { weight }\end{array}$ & $\begin{array}{c}\text { Percent } \\
\text { frequency of } \\
\text { occurrence in } \\
120 \text { transects }\end{array}$ \\
\hline \multicolumn{3}{|l|}{ Perennial grasses } \\
\hline Mesa dropseed (Sporobolus flexuosus) & 10.4 & 91 \\
\hline Black grama (Bouteloua eriopoda) & 3.5 & 39 \\
\hline Fluffgrass (Erioneuron pulchellum) & 1.7 & 75 \\
\hline Spike dropseed (Sporobolus contractus) & 1.0 & 24 \\
\hline Threeawns ( Aristida spp.) & 0.5 & 52 \\
\hline Sand dropseed (Sporobolus cryptandrus) & 0.2 & 8 \\
\hline others & 0.2 & \\
\hline Total Perennial grasses & 17.5 & \\
\hline \multicolumn{3}{|l|}{ Annual grasses } \\
\hline Sixweeks threeawn (Aristida adscensionis) & 0.3 & 23 \\
\hline Needle grama (Bouteloua aristidoides) & 0.2 & 27 \\
\hline Sixweeks grama (Bouteloua barbata) & 0.2 & 33 \\
\hline others & 0.1 & \\
\hline Total annual grasses & 0.8 & \\
\hline \multicolumn{3}{|l|}{$\begin{array}{l}\text { Perennial forbs } \\
\text { Leatherweed croton (Croton pottsii) }\end{array}$} \\
\hline var. Pottsii & 1.2 & 57 \\
\hline $\begin{array}{l}\text { Wooly paperflower (Psilostrophe } \\
\text { tagetina) }\end{array}$ & 1.2 & 28 \\
\hline Twoleaf senna (Cassia bauhinoides) & 0.9 & 56 \\
\hline Fendler bladderpod (Lesquerella fendleri) & 0.4 & 18 \\
\hline $\begin{array}{l}\text { Scarlet globemallow (Sphaeralcea } \\
\text { coccinea var. elata) }\end{array}$ & 0.3 & 24 \\
\hline Silverleaf nightshade (Solanum & & \\
\hline elaeagnifolium) & 0.2 & 57 \\
\hline Trailing rushpea (Hoffmanseggia & & \\
\hline incarnata) & 0.2 & 38 \\
\hline Indian rushpea (Hoffmanseggia glauca) & 0.2 & 40 \\
\hline others & 0.3 & \\
\hline Total perennial forbs & 4.9 & \\
\hline \multicolumn{3}{|l|}{ Annual forbs } \\
\hline Russian thistle (Salsola kali) & 4.0 & 70 \\
\hline Goosefoot (Chenopodium spp.) & 1.6 & 57 \\
\hline Wooly tidestromia (Tidestromia & 0.4 & 36 \\
\hline Wislizenus spectacle pod (Dithyrea & 0.4 & 30 \\
\hline wislizeni) & 0.2 & 22 \\
\hline $\begin{array}{l}\text { Purslane portulaca (Portulaca oleracea) } \\
\text { Rocky Mountain zinnia (Zinnia }\end{array}$ & 0.2 & 14 \\
\hline grandiflora) & 0.2 & 24 \\
\hline others & 0.2 & 74 \\
\hline Total annual forbs & 6.8 & \\
\hline \multicolumn{3}{|l|}{ Woody species } \\
\hline Honey mesquite (Prosopis glandulosa) & 58.0 & 74 \\
\hline $\begin{array}{l}\text { Broom snakeweed (Xanthocephalum } \\
\text { sarothrae) }\end{array}$ & & \\
\hline $\begin{array}{l}\text { sarothrae) } \\
\text { Longleaf ephedra (Ephedra trifurca) }\end{array}$ & $\begin{array}{l}4.7 \\
3.2\end{array}$ & $\begin{array}{l}98 \\
25\end{array}$ \\
\hline Soaptree yucca (Yucca elata) & 3.2 & 73 \\
\hline Fourwing saltbush (Atriplex canescens) & 0.4 & 3 \\
\hline Mescat acacia (Acacia constricta) & 0.3 & 3 \\
\hline Prickly pear cactus (Opuntia spp.) & 0.2 & 4 \\
\hline Total woody species & 70.0 & \\
\hline
\end{tabular}




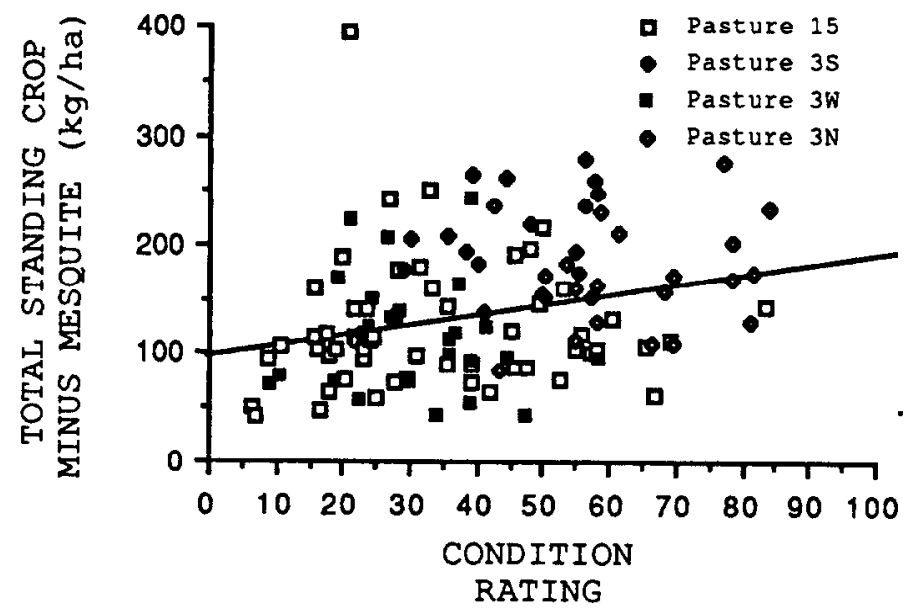

Fig. 2. Total standing crop minus mesquite $(\mathrm{kg} / \mathrm{ha})$ to condition rating. Regression curve is the best fit linear equation: $y=94.9+R^{2}=0.9 x, R^{2}=$ $0.08, P \leq 0.01$.

crop, did not show any significant pattern.

In this study where a large number of samples were collected, data were insufficient to reliably quantify a difference in forage production as related to the Dyksterhuis (1949) method of range condition rating. No reliable relationship was found that could be used to quantify increased forage as succession approached climax.

The results of this study are not in conflict with the range manager's goal to improve range condition. A manager could justify low stocking rates on poor condition range on the assumption that low rates are necessary to improve range condition. However, the results of this study do not support the practice of quantifying the difference in total forage production between range condition classes. The amount of forage production from poor condition range at this site is not sufficiently low to justify recommending lower stocking rates.

Dyksterhuis (1949) pointed out that forage production is generally only a reflectance of range condition and was opposed to the view that range condition be measured directly in terms of forage production as proposed by Humphrey (1947). Lower stocking rate recommendations on poorer condition range were simply guides based upon local experiences to bring about rapid improvement in range condition.

Reduction of stocking rate for reasons to improve condition does not appear justifiable for mesquite-infested range in Southern New Mexico. On the nearby Jornada Experimental Range, complete exclusion of livestock on 259 ha since 1933 has not improved range condition, and by 1963 , the amount of mesquite cover increased from about $50 \%$ to $100 \%$ of the area (Buffington and Herbel 1965). On the other hand, reduction of stocking rate for reasons that less forage may be available on poor condition range is justifiable.

\section{Conclusion}

We found a positive linear relationship for range condition rating and total standing crop minus mesquite, and a negative linear relationship for range condition and total standing crop. The 2 relationships are significant and in the direction expected. However, the subject of importance is the current carrying capacity. Neither model is useful for quantifying carrying capacity as reflected in the correlation coefficients for the linear models. Estimated standing crop could not be accurately predicted from range condition ratings. The relationships were found to have more of a quadratic shape than linear.

The method of rating range condition by species composition as most commonly used appears to be reliable for neither assessing range condition as demonstrated by Anderson (1985), nor quantifying carrying capacity as demonstrated in our study for the Sandy Range Site. Revised methods of condition rating need to be developed that are dependable in assessing range condition. If forage production does in fact increase with increased condition, the method should be useful in quantifying carrying capacity.

\section{Literature Cited}

Anderson, E.W. 1985. Percent composition versus absolute units of measure-a viewpoint. Rangelands 7:247-248.

Beck, R.F. 1978. A grazing system for semiarid lands, p. 569-572. In: D.N. Hyder (ed.) Proc. 1st Int. Rangeland Congr., Society for Range Manage., Denver.

Buffington, L.C., and C.H. Herbel. 1965. Vegetational changes on semidesert grassland range from 1858 to 1963 . Ecol. Monogr. 35:139-164.

Cook, C.W., M. Kothmann, and L.E. Harris. 1965. Effect of range condition and utilization on nutritive intake of sheep on summer ranges. $J$. Range Manage. 18:69-73.

Cook, C.W., and J. Stubbendieck. 1986. Range research: Basic problems and techniques. Soc. Range Manage. Denver, Colo.

Dyksterhuis, E.J. 1949. Condition and management of rangeland based on quantitative ecology. J. Range Manage. 2:104-115.

Humphrey, R.R. 1947. Range forage evaluation by the range condition method. J. Forest. 45:10-16.

Goebel, C.J., and C.W. Cook. 1960. Effect on range condition on plant vigor, production and nutritive value of forage. J. Range Manage. 13:307-313.

Lewis-Beck, M.S. 1986. Applied regression, an introduction. Sage University Paper Series on Quantitative Applications in the Social Sciences, 07-022. Sage Publications, Beverly Hills and London.

Pechanec, J.F., and G.D. Pickford. 1937. A weight estimate method for determination of range or pasture production. J. Amer. Soc. Agron. 29:894-904.

Range Inventory Standardization Committee. 1983. Guidelines and terminology for range inventory and monitoring. Soc. Range Manage., Denver, Colo.

Rosiere, R.E., R.F. Beck, and J.D. Wallace. 1975. Cattle diets on semidesert grassland: Botanical composition. J. Range Manage. 28:89-93.

Smith, E.L. 1979. Evaluation of the range condition concept. Rangelands $1: 52-54$.

United States Department of Agriculture. 1976. National range handbook. Soil Conserv. Serv., Washington, D.C.

United States Department of Agriculture. 1979. Sandy Range Site. Range Site Description, Sec. IIe, Tech. Guide, Soil Conserv. Sery, New Mexico.

United States Department of Commerce. 1977. Climatological data. National Oceanic and Atmospheric Administration, New Mexico.

Westoby, M., B. Walker, and I. Noy-Meir. 1989. Opportunistic management for rangelands not at equilibrium. J. Range Manage. 42:266-274. 